\title{
TUTURAN DEKLARATIF DALAM BAHASA SMS MAHASISWA UNRI PRODI TEKNOLOGI HASIL PERTANIAN TAHUN 2015
}

\author{
Juli Yani, Rismayeti, Hermansyah \\ Fakultas Ilmu Budaya \\ Universitas Lancang Kuning
}

\begin{abstract}
Traditionally, utterances are speech units used in a language directly. It contains series of words and complete thought. The utterances are used in various contexts. One of them is in SMS ( Short Messege Service ). SMS is a facility to send and receive short text messege via wireless device namely telephone mobile communication devices. In this case, the communication device used in cellular telephone. Related to that, this writing presents the analysis of declarative narratives used by students of Agriculture department in Riau University in 2015. It analyzes how the narratives are used and their meanings. Thus, the purpose of the analysis is to identify and describe the meaning of specch utterances of those students.
\end{abstract}

Keywords: declarative utterances, SMS, Students of Riau University.

\section{A. Pendahuluan}

Secara tradisional tuturan didasari oleh suatu akibat bahwa tuturan merupakan satuan bahasa yang secara langsung digunakan dalam bahasa. Sehingga di dalamnya terdapat rangkaian kata dan pikiran lengkap. Dalam pemakaian bahasa secara nyata karena konteks secara penggunaan bahasa, baik konteks kalimat maupun situasi menentukan kelengkapan pikiran tersebut. Namun, konsep rangkaian kata tersebut menimbulkan pertanyaan karena satuan gramatis yang menjadi wujud lahirnya tuturan bisa juga hanya berupa kata (bukan rangkain kata). (lihat Alisjahbana, 1949; Mess, 1950; Poedjawijatna dan Zoetmulder, 1955; Hadidjaja, 1965). Sedangkan secara struktural pengertian tuturan mengandung tiga konsep dasar tetapi berbeda, yakni bentuk satuan gramatikal (kata, frasa atau klausa), dapat berdiri sendiri atau bebas (tidak terikat atau menjadi bagian dari kontruksi yang lebih besar) dan dibatasi oleh kesenyapan awal dan kesenyapan akhir yang berupa intonasi final atau akhir. (lihat Bloomfield, 
1964; Lockett, 1969; Cook, 1971; Kentjono, 1982; Keraf, 1991; Ramlan, 1969).

SMS atau Short Message Service (SMS) merupakan suatu fasilitas untuk mengirim dan menerima suatu pesan singkat berupa teks melalui perangkat nirkabel, yaitu perangkat komunikasi telepon selular, dalam hal ini perangkat nirkabel yang digunakan adalah telepon selular. Salah satu kelebihan dari SMS adalah biaya yang murah. Selain itu SMS merupakan metode store dan forward sehingga keuntungan yang didapat adalah pada saat telepon selular penerima tidak dapat dijangkau, dalam arti tidak aktif atau diluar service area.

SMS pertama kali muncul di belahan Eropa pada tahun 1991 bersama sebuah teknologi komunikasi wireless yang saat ini cukup banyak penggunanya, yaitu Global Sistem for Mobile Communication(GSM). Dipercaya bahwa pesan pertama yang dikirim menggunakan SMS dialakukan pada bulan Desember 1992, dikirim dari sebuah Personal Computer (PC) ke telepon mobile dalam jaringan GSM milik Vodafone Inggris. Perkembagan kemudian merambah ke benua Amerika, dipelopori oleh beberapa operator komunikasi bergerak berbasis digital seperti Bell Sputh Mobility, PrimeCo, Nextel, dan beberapa operator lain. Teknologi digital yang digunakan sangat bervariasi dari yang berbasis GSM, Time Division Multiple Access(TDMA), hingga Code Division Multiple Access(CDMA). Mekanisme cara kerja sistem SMS adalah melakukan pengiriman short message dari satu terminal pelanggan ke terminal yang lain. Hal ini dapat dilakukan berkat adanya sebuah entitas dalam sistem SMS yang bernama Short Message Service Centre (SMSC), disebut juga Message Centre (MC). SMSC merupakan sebuah perangkat yang melakukan tugas store and forward trafik short message. Didalamnya termasuk penentuan atau pencarian rute tujuan akhir dari short message.

Layanan SMS merupakan sebuah layanan yang bersifat non-real time dimana sebuah short dapat disubmit ke suatu tujuan, tidak peduli apakah tujuan tersebut aktif atau tidak. Bila dideteksi tujuan tidak aktif, maka sistem akan menunda pengiriman ke tujuan hingga tujuan aktif kembali. Pada dasarnya sistem SMS akan menjamin delivery dari suatu short message hingga sampai ke tujuan. Kegagalan pengiriman yang bersifat sementara seperti tujuan yang tidak diaktifkan selalu teridentifikasi sehingga pengiriman ulang short message akan selalu dilakukan kecuali bila diberlakukan aturan bahwa short message yang telah melampaui batas 
waktu tertentu harus dihapus dan dinyatakan gagal terkirim.

Penelitian ini akan membahas tuturan deklaratif dalam bahasa SMS mahasiswa Unri Prodi Teknologi Hasil Pertanian tahun 2015. Bentuk dan makna tuturan deklaratif tersebut akan dibahas lebih lanjut.

Metode yang digunakan dalam penelitian ini adalah metode deskriftif kualitatif mengacu pada identifikasi sifat-sifat yang membedakan atau karakteristik sekelompok manusia, benda dan peristiwa. Mely G Tan (Silalahi, 2006:26): "Penelitian yang bersifat deskriftif bertujuan menggambarkan secara tepat dan sifat-sifat suatu individu, keadaan, gejala, atau sekelompok tertentu, atau untuk menentukan frekuensi atau penyebaran suatu gejala atau frekuensi adanya hubungan tertentu antara suatu gejala lain dalam masyarakat. Dalam hal ini mungkin sudah ada hipotesis yang mungkin belum tergantung dari sedikit-banyaknya pengetahuan tentang masalah yang bersangkutan".

Deskriptif dapat diartikan sebagai prosedur pemecahan masalah dengan menggambarkan atau menuliskan keadaan subjek atau objek penelitian pada saat sekarang dengan didukung fakta-fakta yang ada. Penulis menggunakan metode ini guna mendeskripsikan dan mengkaji bentuk-bentuk tuturan deklaratif pada bahasa SMS Mahasiswa Unri Prodi Teknologi Hasil Perikanan Pertanian Tahun 2015.

Adapun teknik dalam penelitian ini adalah teknik pancing dan dokumetasi. Penulis mengirim SMS kepada mahasiswa dan kemudian mahasiswa membalas SMS tersebut. Setelah itu SMS balasan tersebut didokumentasikan.

Data yang penulis dokumentasikan berjumlah 80 SMS. Di samping itu penulis mendokumentasikan SMS yang diterima 8 informan mahasiswa yang dikirim juga oleh mahasiswa tahun 2015 yang ada di Unri Prodi Teknologi Hasil Pertanian. SMS yang didokumentasikan dari informan ada 40 SMS. Berdasarkan prosedur itu, maka penulis memiliki 200 SMS.

Data yang dikumpulkan berdasarkan prosedur pengumpulan data di atas kemudian dianalisis dengan teknik sebagai berikut :

a. SMS dicatat dalam catatan lembar data.

b. Menuliskan arti sebenarnya dari SMS yang telah dicatat.

c. Mengklasifikasi data yang telah dicatat berdasarkan bentukbentuk tuturan deklaratif.

d. Mendeskrifsikan bentuk-bentuk deklaratif yang digunakan dalam SMS. 
Untuk menetapkan keabsahan data, diperlukan teknik pemerisaan yang didasarkan atas sejumlah kriteria tertentu. Menurut Moleong (2005:324) ada 4 kriteria yang digunakan yaitu derajat kepercayaan (credibility), keteralihan (transforbility), ketergantungan (dependability), dan kepastian (comfirmability).

Kriteria keabsahan data yang digunakan adalah kriteria kepastian (comfirmability), yaitu untuk menilai atau menganalisis data secara objektif. Secara objektif dalam tulisan ini diartikan bahwa sesuatu yang objektif tidak digantungkan pada persetujuan beberapa orang mengenai pandangan, pendapat, dan penemuan penulis.

\section{B. Landasan Teori}

\section{B.1 Bahasa}

Bahasa adalah fenomena yang menghubungkan dunia makna dengan dunia bunyi. Lalu, sebagai penghubung di antara kedua dunia itu, bahasa dibangun oleh tiga buah komponen, yaitu komponen leksikon, komponen gramatika, dan komponen fonologi.Kalau bahasa itu merupakan suatu sistem, maka sistem bahasa itu memiliki tiga buah subsistem, yaitu subsistem leksikon, subsistem gramatika, dan subsistem fonologi. Komponen makna berisi konsepkonsep, ide-ide, pikiran-pikiran, atau pendapat-pendapat yang berada dalam otak atau pemikiran manusia. Komponen leksikon dengan satuannya yang disebut leksem merupakan wadah penampung makna secara leksika, juga bersifat abstrak. Komponen gramatika atau subsistem gramatika terbagi lagi menjadi dua subsistem, yaitu subsistem morfologi dan subsistem sintaksis.

Subsistem sintaksis
membicarakan penataan dan
pengaturan kata-kata itu ke dalam
satuan-satuan yang lebih besar, yang
disebut satuan-satuan sintaksis, yakni
kata, frase, klausa, tuturan, dan
wacana. Tuturan umumnya berwujud
rentetan kata yang disusun sesuai
dengan kaidah yang berlaku. Setiap
kata termasuk kelas kata atau kategori
kata, dan mempunyai fungsi dalam
tuturan. Pengurutan rentetan kata serta
macam kata yang dipakai dalam
tuturan menentukan pula macam
tuturan yang dihasilkan.

Jika ditinjau dari segi bentuknya, tuturan dapat berupa tuturan tunggal atau tuturan majemuk. Sedangkan jika dilihat dari segi maknanya tuturan dapat dibedakan menjadi tuturan deklaratif (tuturan berita), tuturan interogatif (tuturan tanya), tuturan deklaratif (tuturan perintah), tuturan eksklamatif (tuturan seruan), dan tuturan emfatik (tuturan penegas). Dilihat dari namanya, sudah tampak 
makna ragam tuturan itu: tuturan berita menyampaikan berita pernyataan, tuturan tanya mengajukan pertanyaan, dan tuturan perintah memberikan perintah kepada yang bersangkutan. Tuturan seruan mengungkapkan perasaan keheranan atau kekaguman atas sesuatu, dan tuturan penegasan khusus kepada pokok pembicaraan.

\section{B. 2 Tuturan}

Tuturan adalah (1) kesatuan ujar yang mengungkapkan suatu konsep pikiran dan perasaan; (2) perkataan; (3) Ling satuan bahasa yang secara relatif berdiri sendiri, mempunyai pola intonasi final dan secara aktual ataupun potensial terdiri atas klausa ( $K B B I$, 2005: 494). Dalam Tata Bahasa Baku Bahasa Indonesia (1988:311) tuturan didefinisikan sebagai satuan bahasa terkecil, dalam wujud lisan atau tulisan, yang mengungkapkan pikiran yang utuh. Dalam wujud lisan, tuturan diucapkan dengan suara naik turun dan keras lembut, disela jeda, dan diakhiri dengan intonasi akhir yang diikuti oleh kesenyapan yang mencegah terjadinya perpaduan atau asmilasi bunyi ataupun proses fonologis lainnya. Dalam wujut tulisan berhuruf Latin, tuturan dimulai dengan huruf kapital dan diakhiri dengan tanda titik.

Berdasarkan tanggapan dari mitra tutur, tuturan dibedakan menjadi tiga, yaitu tuturan berita, tuturan tanya, dan tuturan perintah (KBBI, 2005: 494-
495). Tuturan dilihat dari bentuk sintaksisnya dibedakan menjadi empat, yaitu tuturan deklaratif, tuturan interogatif, tuturan deklaratif, dan tuturan eksklamatif (Hasan Alwi dkk., 1998: 352). Tuturan deklaratif, juga dikenal dengan nama tuturan berita umumnya dipakai pembicara atau penulis untuk membuat pernyataan sehingga isinya merupakan berita bagi pendengar atau pembacanya. Dengan demikian dapat dikatakan bahwa tuturan deklaratif atau tuturan berita dapat berbentuk apa saja (bentuk inversi, aktif, pasif, asal isinya merupakan pemberitaan.

\section{B.3 Deklaratif}

Tuturan deklaratif dalam bahasa Indonesia merupakan tuturan yang mengandung maksud memberitakan sesuatu kepada lawan tutur. Sesuatu yang diberitakannya, umumnya, merupakan pengungkapan suatu peristiwa atau suatu kejadian, baik dalam bentuk tuturan langsung maupun tidak langsung. Tuturan deklaratif yang lebih dikenal dengan tuturan berita atau tuturan pernyataan, jika dibandingkan dengan tuturan lainnya tidak bermarkah khusus. Tuturan deklaratif umumnya digunakan untuk membuat pernyataan sehingga isinya merupakan berita informasi tanpa mengharapkan responsi tertentu. Contohnya apabila kita melihat suatu keadaan dan menyiarkan (menyampaikan) kepada orang lain tentang hal itu maka kita 
dapat menyampaikannya dalam bermacam-macam tuturan berita (deklaratif).

\section{B.4 SMS dan Cara Penulisan SMS}

SMS adalah istilah di bidang telekomunikasi, yaitu layanan pesan singkat, Short Message Service sebuah layanan yang dilaksanakan oleh sebuah ponsel untuk mengirim dan menerima pesan-pesan pendek.SMS banyak digunakan karena kemudahannya. Ketiadaan batasan ruang dan waktu menjadikan SMS sebagai salah satu sarana komunikasi yang dapat diandalkan. SMS adalah bentuk komunikasi pribadi antara pengirim dan penerima pesan. Pesan yang dikirim bersifat formal, informal, canda ria, rahasia, dan bahkan hal-hal yang bersifat amat pribadi. Bentuk pesan yang dikirim bergantung pada kedekatan relasi antarpersonal/tingkat keakraban peserta tutur (Harry Widodo, 2004: 102).

SMS sebagai ragam tulis sebagai layanan pesan singkat menggunakan penyingkatan yang lazim digunakan, misalnya yg (yang), dgn (dengan), sdh (sudah), dll (dan lain-lain). Selain itu terdapat bahasa SMS yang beragam, dari singkatan-singkatan gaul sampai emoticons, adanya space yang terbatas tak harus menghalangi kreativitas dalam penulisan SMS (Dianawati, 2005:v).
Dalam penulisan SMS ditemukan penggunaan singkatan dan akronim khas bahasa SMS, dengan penghilangan vokal dan penggunaan huruf kapital secara "serampangan" (Adhani, 2009:29).

\subsection{Konteks dan Hubungan Penutur dan Mitra Tutur}

Pragmatik adalah cabang ilmu bahasa yang mengkaji penggunaan bahasa berintegrasi dengan tata bahasa (Wijana, 1996: 3). Dalam pragmatik, telaah atas makna tidak dapat dilepaskan atau selalu terikat pada konteks. Konteks sebagai pijakan utama dalam analisis pragmatik terdiri atas siapa mengatakan/berbicara kepada siapa, tempat dan waktu diujarkannya suatu tuturan, anggapananggapan mengenai yang terlibat di dalam tindakan pengutaraan tuturan itu (Kaswanti Purwo, 1990: 14). Komponen tutur yang berkaitan dengan faktor penentu pertuturan tidak cukup hanya mengetahui situsi, peristiwa, dan tindak tutur, melainkan juga komponen tutur.

Menurut Hymes (dalam Sumarsana dan Paina, 2002: 325-335) menjabarkan 16 komponen tutur, yaitu (1) bentuk pesan (message form) menyangkut cara suatu topik dikatakan atau diberitakan, (2) isi pesan (message content) berkaitan dengan persoalan apa yang dikatakan, menyangkut topik dan perubahan 
topik, (3) latar (setting) mengacu kepada waktu dan tempat terjadinya pertuturan atau keadaan fisik, (4) suasana (scene) mengacu kepada latar psikologis, (5) penutur (speaker, sender), (6) pengirim (addressor), (7) pendengar (hearer, receiver, audience), (8) penerima (addressee), (9) maksud-hasil (purpose-outcome), (10) maksud-tujuan (purpose-goal), (11) kunci (key) mengacu kepada cara, nada, atau jiwa (semangat) tindak tutur yang dilakukan, (12) saluran (channel) mengacu kepada mediun penyampaian tutur: lisan, tulisan, telepon, surat, (13) bentuk tutur (formofspeech) mengarah kepada tatanan perabot kebahasaan yang berskala bahasa, dialek, dan variasi yang dipakai secara luas, (14) norma interaksi (norm of interaction), kaidah yang mengatur pertuturan, (15) norma interpretasi (norm of interpretation), (16) genre, dikaitkan dengan kategori seperti puisi, mite, dongeng, peribahasa, doa, orasi.

Dalam Kurikulum Bahasa Indonesia 1984 dirumuskan bahwa pengajaran bahasa bertujuan menumbuhkan kemampuan berkomunikasi dengan bahasa dan dalam berkomunikasi bahasa selalu dikaitkan dengan faktor penentu, yaitu siapa yang berbahasa dengansiapa; untuk tujuan apa; dalam situasi apa (tempat dan waktu); dalam konteks apa (peserta lain, kebudayaan, dan suasana); dengan jalur mana (lisan atau tulisan); media apa (tatap muka, telepon, surat, kawat, buku, koran, dan sebagainya); dalam peristiwa apa (bercakap-cakap, ceramah, upacara, laporan, lamaran kerja, pernyataan cinta, dan sebagainya) (Tarigan, 1986: 179). Faktor penentu di atas dapat disebut konteks pertuturan.

Terkait dengan penutur dan mitra tutur, terjadi komunikasi antarpribadi dengan pola hubungan (1) penutur sejajar dengan mitra tutur dengan hubungan akrab, (2) penutur sejajar dengan mitra tutur dengan jenis hubungan hormat, (3) penutur lebih rendah dibanding mitra tutur dengan jenis hubungan akrab, (4) penutur lebih rendah dibanding mitra tutur dengan jenis hubungan hormat, (5) penutur lebih tinggi dibanding mitra tutur dengan jenis hubungan akrab, dan (6) penutur lebih tinggi dibanding mitra tutur dengan jenis hubungan hormat. Pola hubungan ini tercermin dalam penggunaan kata-katanya.

\section{Hasil dan Pembahasan}

\section{C.1 Analisis Tuturan Deklaratif dalam Bahasa SMS Mahasiswa Unri Prodi Teknologi Hasil Pertanian 2015.}

\section{Data SMS I}

Iyasyah: Aslm Wr.Wb,hasnah sayang lw pagy bsok iyasyah gag msuk tlg 
izini y syng,iyasyah ikut pratikum sayang.

Data SMS 1 termasuk tuturan deklaratif berupa tuturan berita yang bersifat memberitahukan bahwa "AssalamualikumWr.wb, hasnah sayang kalau pagi besok Iyasyah tidak masuk tolong izinin ya sayang,isyasyah ikut pratikum sayang", jadi pengirim sebagai penutur memberitahukan kepada penerima sebagai mitra tutur bahwa penutur member tahukan kalau besok pagi isyasyah tidak dapat hadir ke kampus, dan isyasyah minta tolong kepada mitra tutur agar menyampaikan izinnya. Tuturan deklaratifnya tampak dengan adanya tanda baca diakhir tuturan deklaratif yaitu berupa tanda titik, dan mitra tutur menanggapi pernyataan bersifat pemberitahuan sesuai yang penting kepada mitra tutur. Sehingga penerima menanggapi dengan membalas sms sebagai berikut "iya sayang”.

\section{Data SMS 2}

Dx wanda: $k k$ dsbelah kanan org razia,sblah kiri enggak do.

Data 2 di atas termasuk tuturan deklaratif berupa tuturan berita yang bersifat memberitahukan bahwa "kakak di sebelah kanan orang razia, sebelah kiri tidak do", jadi pengirim sebagai penutur memberitahukan kepada penerima sebagai mitra tutur bahwa penutur membertahukan kalau di sebelah kanan ada razia, dan mitra tutur pemberitahuan tersebut merupakan tuturan deklaratifnya tampak dengan adanya tanda baca di akhir tuturan deklaratif yaitu tanda titik. Dan mitra tutur menanggapi pernyataan bersifat pemberitahuan sesuatu yang penting kepada mitra tutur untuk pemberitahuan yang dideklaratifkan oleh penutur kepada mitra tutur. Sehingga penerima menanggapi dengan membalas sms sebagai berikut "iya lh $d x$, makasih ya $d x "$.

\section{Data SMS 3}

Riko: kasi tw ktman2 kta msuk dgn buk yuli jam 3 druangan biasa ya.

Data SMS 4 termasuk tuturan deklaratif berupa tuturan berita yang bersifat memberitahukan bahwa "kasi tau ke teman-teman kita masuk dengan buk yuli jam 3 di ruang biasa ya", jadi pengirim sebagai penutur memberitahukan kepada penerima sebagai mitra tutur bahwa penutur membertahukan sesuatu yang penting. Mitra tutur pemberitahuan tersebut merupakan tuturan deklaratifnya tampak dengan adanya tanda baca di akhir tuturan deklaratif yaitu ditandai dengan tanda titik. Dan mitra tutur menanggapi pernyataan bersifat pemberitahuan sesuatu yang penting kepada mitra tutur untuk dideklaratifkan oleh penutur kepada mitra tutur. Sehingga penerima menanggapi dengan membalas sms sebagai berikut "iya sayang ". 


\section{Data SMS 4}

Putri: alza, riko udah d kmpus.

Data SMS 4 termasuk tuturan deklaratif berupa tuturan berita yang bersifat memberitahukan bahwa "alza, riko udah d kmpus", jadi pengirim sebagai penutur memberitahukan kepada penerima sebagai mitra tutur bahwa penutur memberitahukan sesuatu yang penting, mitra tutur pemberitahuan tersebut merupakan tuturan deklaratifnya tampak dengan adanya tanda baca di akhir tuturan deklaratif yaitu ditandai dengan tanda titik. Dan mitra tutur menanggapi pernyataan bersifat pemberitahuan sesuatu yang penting kepada mitra tutur untuk dideklaratifkan oleh penutur kepada mitra tutur. Sehingga penerima menanggapi dengan membalas sms sebagai berikut "iya sayang".

\section{Data SMS 5}

Ade : Masih dirumah vista, Kami telat bangun duluan aja presentasinya ya?

Data SMS 5 termasuk tuturan deklaratif berupa berita yang bersifat memberitahukan untuk segera memakai bedak dan baju duluan. Tampak pada tuturan "Masih dirumah vista, Kami telat bangun duluan aja presentasinya ya?", tampak kalau pengirim sebagai penutur memberitahukan kepada penerima sebagai mitra tutur bahwa penutur bangun tidurnya telat dan menyuruh kepada penerima sebagai mitra tutur untuk presentasi terlebih dahulu karena beberapa sebab, tuturan deklaratifnya tampak dengan adanya tanda baca di akhir tuturan deklaratif yaitu tanda tanya “?”. Dan mitra tutur menanggapi pernyataan bersifat perintah kepada mitra tutur untuk melakukan apa yang dideklaratifkan oleh penutur kepada mitra tutur.

\section{C.1.2 Tuturan Deklaratif Perintah dalam SMS}

\section{Data SMS 54}

Putri: vista, bilang sama ika, kunci dalam kotak d bawah kertas itam!,,

Data SMS 54 di atas termasuk tuturan deklaratif berupa tuturan perintah yang bersifat memberitahukan bahwa "vista, bilang samu ika, kunci dalam kotak d bawah kertas itam.!", jadi pengirim sebagai penutur memberitahukan kepada penerima sebagai mitra tutur bahwa penutur memberitahukan sesuatu yang penting, mitra tutur pemberitahuan tersebut merupakan tuturan deklaratifnya tampak dengan adanya tanda baca di akhir tuturan deklaratif berupa perintah yaitu ditandai dengan tanda seru"!". Dan mitra tuturmenanggapi pernyataan bersifat pemberitahuan sesuatu yang penting kepada mitra tutur untuk dideklaratifkan oleh penutur kepada mitra tutur. Sehingga penerima menanggapi dengan membalas sms 
sebagai berikut: $O$ yo lah,tapi Lah tobukak pintu tampak aku nil lah..

\section{Data SMS 55}

katanya hari minggu mau ke pku..!

Data SMS 55 di atas termasuk tuturan deklaratif berupa tuturan perintah yang bersifat memberitahukan bahwa "asslamulaikum apa kbar dex, kapan kesini lagi? Amak katanya hari minggu mau ke pku...!, jadi pengirim sebagai penutur memberitahukan kepada penerima sebagai mitra tutur bahwa penutur memberitahukan sesuatu yang penting, mitra tutur pemberitahuan tersebut merupakan tuturan deklaratifnya tampak dengan adanya tanda baca di akhir tuturan deklaratif berupa perintah yaitu ditandai dengan tanda seru"!"’. Dan mitra tuturmenanggapi pernyataan bersifat pemberitahuan sesuatu yang penting kepada mitra tutur untuk dideklaratifkan oleh penutur kepada mitra tutur. Sehingga penerima menanggapi dengan membalas sms sebagai berikut: $O$ yo lah, besok kak adek ke sana ya kak.

\section{Data SMS 56}

Ade : Lomak main volley ko, main no, kami main d Pasi Panak kinin ko.!.

Data SMS 56 di atas termasuk tuturan deklaratif berupa tuturan perintah yang bersifat memberitahukan bahwa "Lomak main volley ko, main no, kami main d Pasi Panak kinin $k o . .$. !", jadi pengirim sebagai penutur memberitahukan kepada penerima sebagai mitra tutur bahwa penutur memberitahukan sesuatu yang penting, mitra tutur pemberitahuan tersebut merupakan tuturan deklaratifnya berupa perintah tampak dengan adanya tanda baca di akhir tuturan deklaratif yaitu ditandai dengan tanda seru"!'. Dan mitra tutur menanggapi pernyataan bersifat pemberitahuan sesuatu yang penting kepada mitra tutur untuk dideklaratifkan oleh penutur kepada mitra tutur.sehingga penerima menanggapi dengan membalas sms sebagai berikut: Week, main lah,aku main yo d sikonyo, paik te main adok kilie naunyo.

\section{Data SMS 57}

Putri: vista, bilang samu ika, kunci dalam kotak d bawah kertas itam!,,

Data SMS 57 di atas termasuk tuturan deklaratif berupa tuturan perintah yang bersifat memberitahukan bahwa "vista, bilang samu ika, kunci dalam kotak $d$ bawah kertas itam!,,", jadi pengirim sebagai penutur memberitahukan kepada penerima sebagai mitra tutur bahwa penutur memberitahukan sesuatu yang penting, mitra tutur pemberitahuan tersebut merupakan tuturan deklaratifnya berupa perintah tampak dengan adanya tanda baca di akhir tuturan 
deklaratif yaitu ditandai dengan tanda seru"!'. Dan mitra tutur menanggapi pernyataan bersifat pemberitahuan sesuatu yang penting kepada mitra tutur untuk dideklaratifkan oleh penutur kepada mitra tutur. Sehingga penerima menanggapi dengan membalas sms sebagai berikut: oke put siiip... nnti di sampaikan ya.

\section{C.1.3 Tuturan Deklaratif Tanya dalam SMS}

\section{Data SMS 58}

Riko: sdh di mana skrg hasnah, dkmpuong ya?

Data SMS 58 di atas merupakan tuturan deklaratif berupa tanya, tanda deklaratifnya tampak pada tuturan dengan adanya pernyataan yang bersifat memberitahukan yang disampaikan pengirim sebagai penutur kepada penerima sebagai mitra tutur. Tampak pada data di atas terdapatkan tanda baca Tanya seperti " $s d h d i$ mana skrg hasnah, dkmpuong ya?", yang mana pengirim memberikan pernyataan pertanyaan kepada penerima kalau pengirim sebagai penutur bahwa ia sudah berada dikampung. Sehingga penerima sebagai mitra tutur menanggapi pernyataan yang berupa tanya yang di sampaikan penerima sebagai penutur yang tampak pada tuturan penerima "terserah kamu lah, saya tidak tanya kamu". Sehingga komunikasi yang terjadi antara penutur dan mitra tutur melalui sms bersifat komunikatif.

\section{Data SMS 59}

Hasnah: put dmn? Kta udh mly lthn pratikum di ruang c2 ya put.

Data SMS 59 di atas merupakan tuturan deklaratif berupa tanya, tanda deklaratifnya tampak pada tuturan dengan adanya pernyataan yang bersifat memberitahukan yang disampaikan pengirim sebagai penutur kepada penerima sebagai mitra tutur. Tampak pada data di atas terdapatkan tanda baca Tanya seperti " $s d h d i$ mana skrg hasnah, dkmpuong ya?", yang mana pengirim memberikan pernyataan pertanyaan kepada penerima kalau pengirim sebagai penutur bahwa ia sudah berada dikampung. Sehingga penerima sebagai mitra tutur menanggapi pernyataan yang berupa tanya yang di sampaikan penerima sebagai penutur yang tampak pada tuturan penerima "terserah kamu lah, saya tidak tanya kamu”. Sehingga komunikasi yang terjadi antara penutur dan mitra tutur melalui sms bersifat komunikatif.

\section{Data SMS 60}

Hasnah: tari sombng $y$ ? tx $\mathrm{mw} b l z$ smz hasnah skrg e?

Data SMS 60 di atas merupakan tuturan deklaratif berupa tanya, tanda deklaratifnya tampak pada tuturan 
dengan adanya pernyataan yang bersifat memberitahukan yang disampaikan pengirim sebagai penutur kepada penerima sebagai mitra tutur. Tampak pada data di atas terdapatkan tanda baca Tanya seperti "tari sombng y? tx mw blz smz hasnah skrg e?", yang mana pengirim memberikan pernyataan pertanyaan kepada penerima kalau pengirim sebagai penutur mempertanyakan kenapa mitra tuturnya sekarang sombong sehingga tidak mau membalas sms yang selalu dikirimkannya. Sehingga penerima sebagai mitra tutur menanggapi pernyataan yang berupa tanya yang di sampaikan penerima sebagai penutur yang tampak pada tuturan penerima "gk kok nah,, skrg Tari sibuk". Sehingga komunikasi yang terjadi antara penutur dan mitra tutur melalui sms bersifat komunikatif.

\section{Data SMS 61}

Vista: hasnah, ta d pasar, tik klu dah sampai kunci d bawah pot, mau beli apa,?

Data SMS 61 di atas merupakan tuturan deklaratif berupa tanya, tanda deklaratifnya tampak pada tuturan dengan adanya pernyataan yang bersifat memberitahukan yang disampaikan pengirim sebagai penutur kepada penerima sebagai mitra tutur. Tampak pada data di atas terdapatkan tanda baca Tanya seperti "hasnah, ta d pasar, tik klu dah sampai kunci d bawah pot, mau beli apa,?", yang mana pengirim memberikan pernyataan pertanyaan kepada penerima kalau pengirim sebagai penutur bahwa dia berada di pasar dan mau dibelikan sesuatu. Sehingga penerima sebagai mitra tutur menanggapi pernyataan yang berupa tanya yang di sampaikan penerima sebagai penutur yang tampak pada tuturan penerima "boleh, , belikan sate aja ya”. Sehingga komunikasi yang terjadi antara penutur dan mitra tutur melalui sms bersifat komunikatif.

\section{Data SMS 62}

Ria :ria dah mkn dh endang???

Data SMS 62 di atas merupakan tuturan deklaratif berupa tanya, tanda deklaratifnya tampak pada tuturan dengan adanya pernyataan yang bersifat memberitahukan yang disampaikan pengirim sebagai penutur kepada penerima sebagai mitra tutur. Tampak pada data di atas terdapatkan tanda baca Tanya seperti "ria dah mkn dh endang???", yang mana pengirim memberikan pernyataan pertanyaan kepada penerima kalau pengirim sebagai penutur mempertanyakan kenapa mitra tuturnya tetang sudah makan atau belum. Sehingga penerima sebagai mitra tutur menanggapi pernyataan yang berupa tanya yang di sampaikan penerima sebagai penutur yang tampak 
pada tuturan penerima "makan bareng yuk?". Sehingga komunikasi yang terjadi antara penutur dan mitra tutur melalui sms bersifat komunikatif.

\section{Data SMS 63}

Ria: Td msk ikn tri, endang mkn ap?

Data SMS 63 di atas merupakan tuturan deklaratif berupa tanya, tanda deklaratifnya tampak pada tuturan dengan adanya pernyataan yang bersifat memberitahukan yang disampaikan pengirim sebagai penutur kepada penerima sebagai mitra tutur. Tampak pada data di atas terdapatkan tanda baca Tanya seperti "Td msk ikn tri, endang mkn ap?", yang mana pengirim memberikan pernyataan pertanyaan kepada penerima kalau pengirim sebagai penutur menyatakan kalau dia sudah masak ikan tri, dan mempertanyakan mitra tuturnya apa apa tadi?. Sehingga penerima sebagai mitra tutur menanggapi pernyataan yang berupa tanya yang di sampaikan penerima sebagai penutur yang tampak pada tuturan penerima "makan bareng yuk?". Sehingga komunikasi yang terjadi antara penutur dan mitra tutur melalui sms bersifat komunikatif.

\section{Data SMS 64}

Endang: ria, bsok bwa filmny y?

Data SMS 64 di atas merupakan tuturan deklaratif berupa tanya, tanda deklaratifnya tampak pada tuturan dengan adanya pernyataan yang bersifat memberitahukan yang disampaikan pengirim sebagai penutur kepada penerima sebagai mitra tutur. Tampak pada data di atas terdapatkan tanda baca Tanya seperti "ria, bsok bwa filmny y?", yang mana pengirim memberikan pernyataan pertanyaan kepada penerima bisakah mitra tutur membawa filmnya ke kampus. Sehingga penerima sebagai mitra tutur menanggapi pernyataan yang berupa tanya yang di sampaikan penerima sebagai penutur yang tampak pada tuturan penerima "ya dang,,ria bawak ya". Sehingga komunikasi yang terjadi antara penutur dan mitra tutur melalui sms bersifat komunikatif.

\section{Data SMS 65}

Ade: putri, sombng y? tx mw blz smz ade skrg $e$ ?

Data SMS 65 di atas merupakan tuturan deklaratif berupa tanya, tanda deklaratifnya tampak pada tuturan dengan adanya pernyataan yang bersifat memberitahukan yang disampaikan pengirim sebagai penutur kepada penerima sebagai mitra tutur. Tampak pada data di atas terdapatkan tanda baca Tanya seperti "putri, sombng y? tx mw blz smz ade skrg $e$ ?', yang mana pengirim memberikan pernyataan pertanyaan kepada penerima kalau dia sekarang sudah sombong sampai gak bisa membalas sms yang selalu dikirimkannya. Sehingga penerima sebagai mitra tutur 
menanggapi pernyataan yang berupa tanya yang di sampaikan penerima sebagai penutur yang tampak pada tuturan penerima "gak kok de,, putrid skrg lagi sibuk,,". Sehingga komunikasi yang terjadi antara penutur dan mitra tutur melalui sms bersifat komunikatif.

\section{Data SMS 66}

Endang: jadi, nebeng ria malam minggu ni???..

Data SMS 66 di atas merupakan tuturan deklaratif berupa tanya, tanda deklaratifnya tampak pada tuturan dengan adanya pernyataan yang bersifat memberitahukan yang disampaikan pengirim sebagai penutur kepada penerima sebagai mitra tutur. Tampak pada data di atas terdapatkan tanda baca Tanya seperti "jadi, nebeng ria malam minggu ni???..", yang mana pengirim memberikan pernyataan pertanyaan kepada penerima yang mempertanyakan jadi nginap di kosnya pada malam minggu atau tidak. Sehingga penerima sebagai mitra tutur menanggapi pernyataan yang berupa tanya yang di sampaikan penerima sebagai penutur yang tampak pada tuturan penerima "jadi donk,, nnti dikabari lagi ya dang,", Sehingga komunikasi yang terjadi antara penutur dan mitra tutur melalui sms bersifat komunikatif.

\section{Simpulan}

Berdasarkan hasil analisis tentang tuturan deklaratif dalam bahasa SMS mahasiswa Prodi Teknologi Hasil Pertanian tahun 2015 dapat disimpulkan sebagai berikut:

Dalam short Message Service (SMS) ditemukan tuturan deklaratif dalam bentuk tuturan deklaratif biasa, tuturan deklaratif permintaan, tuturan deklaratif ajakan, tuturan deklaratif pemberian izin, tuturan deklaratif suruhan. Dari hasil analisis yang telah dilakukan, bentuk tuturan deklaratif berita paling banyak ditemukan (56 SMS), urutan selanjutnya bentuk tuturan deklaratif tanya (20 SMS), dan terakhir tuturan deklaratif perintah (4 SMS). Dari data ini tergambar bahwa kebanyakan mahasiswa mengunakan tuturan deklaratif berita dalam SMS yang mereka kirimkan ke mitra tutur (penerima SMS).

Temuan selanjutnya adalah terdapat dua makna tuturan deklaratif dalam SMS mahasiswa tersebut, yaitu makna perintah dan makna permohonan. Sementara untuk makna deklaratif pembiaran hanya sedikit data SMS yang ditemukan.

\section{DAFTAR PUSTAKA}

Adhani, Agnes. 2009. Perbandingan Bahasa Surat Pembaca Majalah Kawanku dan Hai. 
Alwi, Hasan. dkk. 1998. Tata Bahasa

Baku Bahasa Indonesia. Jakarta:

Balai Pustaka.

Laporan Penelitian tidak dipublikasikan. Madiun: Universitas Widya Mandala Madiun.

Departemen Pendidikan dan Kebudayaan.1988. Tata Bahasa Baku Bahasa Indonesia. Jakarta: Balai Pustaka.

Mahsun. 2005. Metode Penelitian Bahasa. Jakarta: Raja Grafindo Persada.

Tarigan, Henry Guntur. 1991. Pengajaran Sintaksis. Bandung: Angkasa 